\title{
PENGARUH KOMITMEN MANAJEMEN PUNCAK DAN PERAN AKUNTAN MANAJEMEN TERHADAP SISTEM INFORMASI LINGKUNGAN DAN DAMPAKNYA KEPADA KINERJA LINGKUNGAN
}

\author{
Toto Kurniawan \\ Ririn Breliastiti \\ Universitas Bunda Mulia \\ tkurniawan@bundamulia.ac.id
}

\begin{abstract}
Disclosure of information about environmental performance (environmental performance information) to external parties is an important step to show that the company is a good corporate citizenship. Top management realized that the commitment on environmental sustainability can provide a competitive advantage to companies through reduced costs, increased market share, image enhancement and technological leadership. In addition, the role of the management accountant had already increasingly taken into account. The seriousness of top management and company management accountants will be reflected in the establishment of an information system in which to accommodate information about the environment. In practice, most companies do not have adequate systems for measuring and managing environmental costs, or coordinate the collection of environmental data for managerial decisions. This study aims to determine the effect of directly or indirectly from the top management commitment and the role of the management accountant which is mediated by the information system environment on environmental performance. The population in this study are private companies that are domiciled or headquartered in Jakarta. The method of selecting samples using a convenience sampling and purposive sampling. Respondents who have been targeted in this research is the employee who has occupied the minimum level supervisor. The data used are primary data collected through questionnaires. Data analysis was performed using analysis of PLS (Partial Least Squares). The results showed that the top management commitment, both directly and indirectly affect the environmental performance. The role of the management accountant directly affect environmental performance. Environmental information system influence on environmental performance.
\end{abstract}

Keywords: top management commitment, the role of management accountants, environmental information systems, environmental performance, management accounting

\section{Pendahuluan}

\subsection{Latar Belakang Masalah}

Dalam kurun beberapa tahun terakhir ini perusahaan dan organisasi merasakan dampak dari adanya tekanan dari para stakeholder, seperti konsumen, investor, pemerintah, media, karyawan dan lembaga swa- 
daya masyarakat. Tekanan dan perhatian dari stakeholder yang mengarah pada kinerja lingkungan ini kemudian mendorong banyak institusi mempertimbangkan untuk menerapkan social and environmental accounting. Pengungkapan informasi kinerja lingkungan (environment performance information) kepada pihak eksternal merupakan langkah penting untuk menunjukkan bahwa perusahaan adalah corporate citizenship yang baik.

Selama proses menangani masalah etika dan ekologi yang berkaitan dengan publik, beberapa manajemen puncak menyadari bahwa komitmen atas keberlanjutan lingkungan dapat memberikan keunggulan kompetitif kepada perusahaan melalui pengurangan biaya, peningkatan pangsa pasar, peningkatan citra dan kepemimpinan teknologi. Selain itu, peran para akuntan manajemen pun sudah makin diperhitungkan. Kese-riusan dari manajemen puncak dan akuntan manajemen perusahaan akan tercermin pada dibentuknya suatu sistem informasi yang di dalamnya mengakomodir informasi mengenai lingkungan.

Berkaitan dengan hal tersebut di atas, dalam prakteknya sebagian besar perusahaan tidak memiliki sistem yang memadai untuk mengukur dan mengelola biaya lingkungan, ataupun mengkoordinasikan pengumpulan data lingkungan untuk keputusan manajerial (Joshi et al., 2001). Diantara mereka hanya sedikit yang telah berinvestasi untuk mengembangkan sistem informasi akuntansi lingkungan. Hal tersebut dikarenakan kurangnya pemahaman akan akuntansi lingkungan sehingga berdampak pada hilangnya peluang untuk meningkatkan kinerja lingkungan dan ekonomi.

\subsection{Identifikasi Masalah}

Dalam lingkup perusahaan di Indonesia, akuntansi lingkungan (environmental accounting) masih sedikit dibahas dalam kajian literatur yang ada. Penelitian yang terkait dengan komitmen manajemen puncak, peran akuntan manajemen, sistem informasi akuntansi lingkungan dan kinerja lingkungan masih sangat terbatas dibahas dalam 
penelitian di Indonesia. Hal inilah yang menjadikan motivasi bagi peneliti untuk melakukan penelitian yang dapat memberikan bukti empiris bahwa terdapat keterkaitan yang erat antara komitmen mana-jemen puncak, peran akuntan manajemen, sistem informasi akun-tansi lingkungan, terhadap kinerja lingkungan. Harapannya adalah perusahaan akan mulai menerapkan akuntansi lingkungan sebagai strategi untuk mencapai kinerja lingkungan yang diharapkan oleh para stakeholder.

\subsection{Perumusan Masalah}

a. Apakah komitmen manajemen puncak berpengaruh terhadap kinerja lingkungan?

b. Apakah komitmen manajemen puncak melalui sistem informasi lingkungan berpengaruh terhadap kinerja lingkungan?

c. Apakah peran akuntan manajemen berpengaruh terhadap kinerja lingkungan?

d. Apakah peran akuntan manajemen melalui sistem informasi lingkungan berpengaruh terhadap kinerja lingkungan? e. Apakah sistem informasi lingkungan berpengaruh terhadap kinerja lingkungan?

\subsection{Batasan Masalah}

Terdapat banyak faktor yang memengaruhi kinerja lingkungan. Dalam penelitian ini, variabel yang akan diteliti dibatasi pada sistem informasi lingkungan yang menjadi mediasi bagi komitmen manajemen puncak dan peran akuntan manajemen.

\section{Tinjauan Pustaka}

\subsection{Komitmen Organisasi}

Porter et al. (1974) dalam Tutuncu \& Kucukusta (2007) mendefinisikan komitmen organisasi sebagai kekuatan dalam identifikasi dan keterlibatan individu dengan organisasi tertentu. Komitmen ini ditandai oleh tiga faktor:

a. Keyakinan yang kuat dan penerimaan atas tujuan dan nilainilai organisasi.

b. Kemauan untuk mengerahkan usaha yang cukup atas nama organisasi.

c. Keinginan untuk mempertahankan keanggotaan organisasi. 
Dalam penelitian Tutuncu \& Kucukusta (2007) dikutip pendapat dari beberapa peneliti yang menyatakan bahwa menurut teori perilaku organisasi, komitmen organisasi terdiri dari tiga tipe:

a. Komitmen dalam affective evaluation, yang disebut dengan affective commitment (Meyer \& Allen, 1997), psychological attachment melalui identifikasi (O'Reilly \& Chatman, 1986) atau keterlibatan (Mowday et al., 1982). Komitmen ini terjadi karena adanya pengaruh dari pihak eksternal.

b. Komitmen karena tunduk pada kewajiban kepada organisasi, yang disebut dengan normative commitment (Meyer et al., 1989), moral commitment (Penley \& Gould, 1988), atau internalization. Komitmen ini terjadi karena adanya peraturan.

c. Komitmen karena adanya hubungan antara biaya dan penghargaan dengan kelanjutan karyawan, yang disebut dengan continuance commitment (Meyer et al., 1989), calculative commitment (Penley \& Gould, 1988), atau compliance commitment
(O'Reilly \& Hatman, 1986).

Komitmen ini terjadi karena adanya keinginan untuk melanjutkan bekerja.

Hasil penelitian Tutuncu \& Kucukusta (2007) menyatakan bahwa terdapat hubungan yang kuat antara organizational commitment (OC) dengan business excellence model (BEM). Diantara ketiga tipe komitmen organisasi, urutan teratas adalah berasal dari affective commitment. Hal ini dikarenakan nilai emosional lebih dihargai oleh karyawan dibandingkan dengan faktor lainnya. Berikutnya adalah continuance commitment, dan terakhir adalah normative commitment.

Menurut Rego dan Cunha (2008) komitmen merupakan variabel sentral dimana orang yang memiliki komitmen cenderung untuk mencurahkan usaha yang lebih tinggi untuk bekerja, sehingga akan memberikan kontribusi bagi kinerja organisasi. Komitmen organisasi didefinisikan sebagai keadaan psikologis yang mencirikan hubungan antara karyawan dengan organisasi yang akan mengurangi kemungkinan karyawan tersebut akan mengundurkan diri 
(Allen dan Meyer, 2000; dalam Rego dan Cunha, 2008).

\subsection{Komitmen Manajemen Puncak}

Manajemen puncak memiliki peran penting dalam membentuk organisasi. Penelitian yang dilakukan atas implementasi strategi menunjukkan bahwa strategi organisasi mencerminkan karakteristik dan kepentingan manajemen puncak perusahaan (Hambrick dan Mason, 1984; dalam Tzempelikos, 2015). Salah satu peran kunci manajemen adalah partisipasinya dalam pengambilan keputusan (Homburg et al., 2002; dalam Tzempelikos, 2015).

Strategi bisnis bila dilihat dari sudut pandang lingkungan memiliki banyak manfaat lingkungan. Jika Organisasi mengkonsumsi energi, bahan dan menyisakan limbah yang berorientasi pada TQ, maka akan terbentuklah pengelolaan ling-kungan. Hal ini merupakan hal penting bagi program penyebaran strategis (programme of strategic deployment ) untuk mendukung per-baikan lingkungan yang ber-kelanjutan (Lawrence et al. 1998).

\subsection{Peran Akuntan Manajemen}

Penelitian yang dilakukan oleh Deegan et al. (1995) dalam Medley (1997) memberikan bukti bahwa kebanyakan akuntan pada periode tersebut tidak mempertimbangkan bahwa lingkungan merupakan hal yang relevan dengan profesi mereka. Dalam rangka mencari peran akuntan (di luar peran akuntan keuangan), saat ini peran tersebut telah berfokus pada akuntan manajemen yang memperkenalkan perspektif biaya dan manfaat lingkungan. Peran kunci dari akuntan manajemen adalah mengidentifikasi dan mengelola biaya lingkungan.

Akuntan perlu menyadari dan ikut terlibat dalam masalah lingkungan. Di Australia, the Institute of Chartered Accountants dan the Society of Certified Practising Accountants aktif meneliti akuntansi lingkungan dan peran yang harus diemban oleh profesi ini di masa depan. Banyak negara yang telah berinisiatif dalam akuntansi lingkungan termasuk Kanada, Amerika Serikat dan Inggris, di mana profesi akuntan mengambil peran aktif dalam masalah lingkungan (Medley, 1997). 
Dalam rangka meningkatkan pengetahuan dari para akuntan, dua bidang utama perlu untuk diadakan. (1) Pelatihan untuk akuntan, agar akuntan dapat memahami isu-isu lingkungan beserta dampaknya. (2) Menyediakan pedoman, agar para akuntan dapat mengukur dan melaporkan hal-hal yang terkait dengan isu lingkungan dengan dasar yang sama (Medley, 1997).

Akuntansi adalah sistem pengukuran yang penting dari kegiatan bisnis. Oleh karena itu, terdapat tekanan bagi akuntansi dan akuntan pro-fesional untuk lebih mengin-tegrasikan keberlanjutan dalam pengambilan keputusan sistem korporasi untuk mengarahkan peri-laku mereka terhadap pembangunan berkelanjutan. Peran akuntansi menjadi lebih penting, terutama ketika ketidakcukupan dalam sumber daya alam dan masalah-masalah sosial meningkat bagi generasi sekarang dan mendatang (Caliskan, 2014).

Penelitian yang dilakukan oleh Chartered Institute of Management Accountants (CIMA, 2011) melalui survei pada tahun 2003, 2006 dan 2010, menjelaskan hal-hal sebagai berikut:
(1) Tuntutan kepada para akuntan manajemen telah berkembang sejalan dengan tumbuhnya tantangan dari masalah sosial dan lingkungan. Para akuntan dituntut untuk memberikan informasi dan dampak dari keputusan.

(2) Akuntan manajemen diharapkan memiliki posisi kepemimpinan yang kuat terkait sustainability accounting dan pengumpulan informasi non-finansial.

(3) Akuntan manajemen dapat berperan penting sebagai fasilitator dan kolaborator atas aktivitas-aktivitas yang terintegrasi.

(4) Dibutuhkan banyak akuntan manajemen yang memahami financial sustainability yang disampaikan kepada stakeholder dan masyarakat yang luas, tidak sekedar kepada para shareholder.

(5) Akuntan manajemen yang baik adalah akuntan yang memiliki pendekatan yang berimbang. Penekanan peran akuntan manajemen adalah melayani kepentingan yang luas bukan murni menjadi akuntan saja.

(6) Jauh dari harapan di atas, berdasarkan survei ternyata 
akuntan manajemen di Selandia Baru pada tahun 2011 tidak memainkan peran penting dalam mengembangkan strategi lingkungan dan sosial. Hanya 5\% responden dari perusahaan besar yang memiliki akuntan yang berperan. Akuntan manajemen anggota CIMA hanya $12 \%$ yang terlibat dalam environmental strategy.

(7) Diharapkan akuntan manajemen generasi berikutnya dapat berkolaborasi dengan top management dalam mengintegrasikan kesejahteraan finansial masyarakat dan kesejahteraan finansial stakeholder.

\subsection{Sistem Informasi Akuntansi Lingkungan}

Environmental accounting adalah termasuk dalam bidang akuntansi yang menyediakan laporan untuk pengguna internal, yaitu menghasilkan informasi lingkungan untuk membantu manajemen dalam membuat keputusan harga, dan untuk para pengguna eksternal yaitu mengungkapkan informasi lingkungan untuk publik yang menaruh perhatian dan komunitas keuangan. Untuk peng- gunaan internal, lebih dikenal dengan terminologi environmental management accounting (Bartolomeo et al., 2000; dalam Yakhou dan Dorweiler, 2004).

Environmental management system bertujuan untuk menghasilkan (1) pengurangan emisi dan limbah, (2) disain produk untuk lingkungan, (3) efisiensi energi dan konservasi, (4) peluang untuk menambah dampak lingkungan (Yakhou dan Dorweiler, 2004).

\subsection{Keberlanjutan dan Kinerja Lingkungan}

Konsep sustainable development pertama kali diperkenalkan oleh the Brundtland Commission pada tahun 1987. Sustainable development memiliki gagasan bahwa memenuhi kebutuhan masa kini tanpa mengorbankan kemampuan generasi mendatang untuk memenuhi kebutuhan mereka sendiri. Konsep ini semakin diperkenalkan dalam manajemen strategi dalam rangka mempertimbangkan faktor-faktor seperti pelestarian lingkungan, kesejahteraan sosial atau hak asasi manusia (Moneva et al., 2007; dalam Moneva 
dan Ortas, 2010). Sustainable development melibatkan perubahan signifikan dalam model manajerial tradisional, terutama fokus pada gagasan pada memaksimalkan nilai pemegang saham.

Ilinitch et al. (1998) mencoba untuk merumuskan empat dimensi konseptual untuk menilai corporate environmental performance, yaitu (1) organizational systems; (2) stakeholder relations; (3) regulatory compliance; dan (4) environmental impacts 
Tabel 2.1

Dimensi Konseptual Penilaian Corporate Environmental Performance

\begin{tabular}{|c|c|}
\hline Dimensi & Pengukuran \\
\hline \multirow[t]{5}{*}{ Organizational systems } & - $\quad$ Number of environmental staff \\
\hline & - Existence of board of directors committee \\
\hline & - Level of environmental reporting responsibility \\
\hline & - Environmental TQM \\
\hline & - US audits conducted \\
\hline \multirow[t]{4}{*}{ Stakeholder relations } & - $\quad$ Total PAC contributions \\
\hline & $\begin{array}{l}\text { - PAC contributions to congressmen with poor environmental } \\
\text { voting records }\end{array}$ \\
\hline & - Disclosure of capital expenditures \\
\hline & - Disclosure of operations/maintenance expenses \\
\hline \multirow[t]{3}{*}{ Regulatory compliance } & - $\quad$ Toxic releases \\
\hline & - $\quad$ Number of chemical spills \\
\hline & - $\quad$ Number of superfund sites \\
\hline \multirow[t]{4}{*}{ Environmental impacts } & - $\quad$ Number of government proceedings \\
\hline & - $\quad$ Number of RCRA permit denials \\
\hline & - $\quad$ Number of RCRA corrective actions \\
\hline & - $\quad$ Amount of RCRA penalties \\
\hline
\end{tabular}

Sumber: Ilinitch et al. (1998)

\subsection{Kerangka Pemikiran}

Gambar 2.1

Model Penelitian
Variabel Independen
Variabel Intervening
Variabel

Dependen

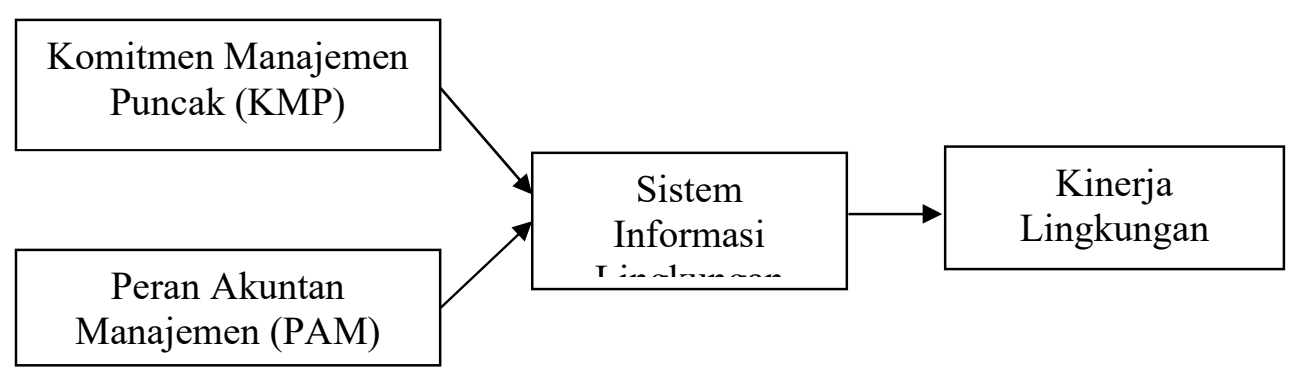

\subsection{Hipotesis Penelitian}

\subsubsection{Komitmen Manajemen Puncak dan Kinerja Ling-kungan}

Penelitian yang dilakukan oleh

Spencer et al. (2013) yang menguji pengaruh antara komitmen mana- jemen puncak dengan kinerja lingkungan memberikan hasil bahwa terdapat pengaruh antara komitmen manajemen puncak dengan kinerja lingkungan. Penelitian ini dilakukan atas 200 perusahaan teratas pada the 
Australian Stock Exchange (ASX), dimana para respondennya adalah para chieffinancial officer (CFO) dan chief management officer (CMO). Penelitian yang dilakukan atas lima perusahaan elektronik di Jepang menjelaskan bahwa kelima perusahaan tersebut memiliki presiden direktur yang berkomitmen atas kewajiban lingkungan perusahaan mereka. Komitmen tersebut dijalankan dengan serius sejak tahun 1990-an dan berdampak pada kinerja lingkungan Takagaki (2009).

Berdasarkan kedua penelitian di atas dapat disimpulkan bahwa komitmen manajemen puncak sangat dibutukan oleh perusahaan yang ingin mencapai kinerja lingkungan. Tanpa komitmen, maka kesadaran peru-sahaan akan kewajiban lingkungan yang bertujuan untuk mencapai kinerja lingkungan akan sulit untuk dicapai.

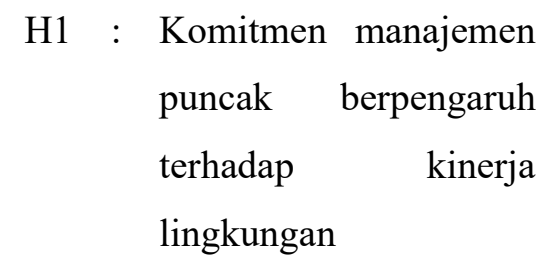

\subsubsection{Komitmen Manajemen Pun- cak, Sistem Informasi Ling-}

\section{kungan dan Kinerja Ling- kungan}

Menurut Dong (2001), komitmen manajemen puncak merupakan faktor yang paling banyak dipelajari dalam kesuksesan implementasi sistem informasi (IS). Sebuah tinjauan literatur telah menemukan bahwa komitmen manajemen puncak atas sumber daya (TMCR) meru-pakan fokus dari banyak studi (Newman dan Sabherwal, 1996; dalam Dong, 2001). Namun, kurangnya komitmen untuk mengu-bah manajemen diakui sebagai sum-ber yang paling sulit dalam pelak-sanaan IS, terutama implementasi IS yang melibatkan perubahan organi-sasi yang mendasar.

Annandale et al. (2004) meneliti sejauh mana pelaporan lingkungan perusahaan dan sistem manajemen lingkungan telah memengaruhi pelaporan lingkungan melalui survei atas 40 perusahaan di Australia Barat. Penelitian melaporkan hubungan positif antara penerapan sistem manajemen lingkungan dan kesadaran akan lingkungan. Hal ini dapat dicapai melalui pelatihan 
karyawan yang tepat dan fokus pada tanggung jawab staf senior.

Komitmen manajemen puncak untuk keberlanjutan lingkungan dapat dianggap sebagai respon terhadap jenis tekanan eksternal yang terdiri dari tekanan publik, ekonomi dan budaya perusahaan (Roy et al., 2001).

Sistem informasi lingkungan beroperasi dengan fokus khusus pada informasi bahan dan aliran energi dan informasi biaya lingkungan. Hal ini dapat dihasilkan melalui sistem akuntansi manajemen (MAS) dan mencakup semua jenis kegiatan terkait pengelolaan lingkungan, termasuk: desain produk dan proses; kontrol biaya dan alokasi; harga produk; akuisisi atau modifikasi peralatan modal; manajemen rantai pasokan; dan evaluasi kinerja. Karena data kinerja lingkungan yang dilaporkan terutama untuk manajemen, proses pengumpulan data lingkungan dapat dihubungkan dengan sistem informasi manajemen untuk keperluan pelaporan internal (Schaltegger et al., 2003; dalam Spencer et al. 2013).
Untuk dapat mencapai integrasi dalam sistem manajemen lingkungan, komponen utama yang harus diimplementasikan adalah adanya komitmen manajemen senior untuk kebijakan lingkungan (Rondinelli dan Vastag, 2000; dalam Yakhou dan Dorweiler, 2004).

Penelitian yang menguji pengaruh komitmen manajemen puncak, sistem informasi lingkungan dan ki-nerja lingkungan telah dilakukan oleh Albelda-Pe'rez et al. (2007) yang menemukan bahwa komitmen manajemen mendefinisikan karakteristik dari suatu sistem manajemen lingkungan yang bertindak sebagai katalis untuk terjadinya perubahan. Sementara Lee dan Ball (2003) dalam Spencer et al. (2013) menemukan bahwa komitmen manajemen puncak memiliki dampak langsung pada bagaimana organisasi menanggapi isu-isu lingkungan dan dalam perumusan strategi. Wee dan Quazi (2005) mengidentifikasi komitmen manaje-men untuk lingkungan sebagai faktor penting dalam menilai dan meningkatkan praktek pengelolaan lingkungan. Demikian pula penelitian 
Spencer et al. (2013) yang memberikan hasil bahwa komitmen manajemen puncak melalui sistem informasi lingkungan berpengaruh terhadap kinerja lingkungan.

Dari uraian di atas, penelitian ini bertujuan untuk menguji pengaruh antara komitmen manajemen puncak untuk kelestarian lingkungan terhadap kinerja lingkungan dan untuk menguji model mediasi di mana penerapan sistem informasi lingkungan dianggap sebagai mekanisme dampak komitmen manajemen puncak untuk kelestarian lingkungan untuk meningkatkan kinerja lingkungan.

\section{$\mathrm{H} 2$ : Komitmen manajemen puncak melalui sistem informasi lingkungan berpengaruh terhadap kinerja lingkungan}

\subsubsection{Peran Akuntan Manajemen dan Kinerja Lingkungan}

Akuntan manajemen memiliki kontribusi yang signifikan dalam perbaikan kinerja lingkungan (Birkin, 1996). Kontribusi ini terkait dengan penerapan akuntansi mana-jemen lingkungan (EMA) dalam perusahaan.

Peran akuntan tergantung pada tanggung jawabnya. Akuntan terlibat dalam audit lingkungan melalui program audit internal, untuk menilai proposal investasi untuk memperoleh manfaat lingkungan, dengan analisis limbah dan biaya energi, dan untuk penyediaan informasi untuk mendukung pengelolaan lingkungan (Gray et al., 1993; dalam Mistry et al., 2014). Secara historis, peran akuntan manajemen telah dikaburkan oleh peran utama dari akuntan yang terlibat dalam pelaporan keuangan, audit, dan kegiatan perpajakan (Parker, 2000).

Namun, dengan berlalunya waktu, peran tradisional akuntan manajemen telah berevolusi (Albelda, 2011). Burnett dan Hansen (2008) dan Myburgh (2001) menyatakan bahwa bukti empiris menunjukkan bahwa hubungan yang meningkat antara kinerja lingkungan dan ekonomi, sehingga akuntan manajemen memiliki peran sebagai fasilitator pengambilan keputusan. Albelda (2011) menunjukkan bagaimana peran akuntan manajemen dan praktik 
akuntansi bertindak sebagai fasilitator pembangunan berkelan-jutan.

Penelitian Mistry et al. (2014) menjelaskan mengenai peran akuntan manajemen dalam suatu organisasi terkait erat dengan sebuah organisasi yang memiliki tujuan untuk mencapai pembangunan berkelanjutan. Tujuan organisasi dapat menjadi refleksi bagaimana beberapa organisasi dan akuntan manajemen melihat konsep pem-bangunan berkelanjutan.

Dari uraian di atas, penelitian ini ingin menguji peran akuntan mana-jemen terhadap kinerja lingkungan.

H3 : Peran akuntan manajemen

berpengaruh terhadap kinerja lingkungan

\subsubsection{Peran Akuntan Manajemen,} Sistem Informasi Lingkungan dan Kinerja Lingkungan

Beberapa penelitian telah dilakukan untuk menguji pengaruh peran akuntan manajemen terhadap kinerja lingkungan. Penelitian tersebut adalah Birkin (1996), Mistry et al. (2014), Burnet dan Hansen (2008), Myburgh (2001). Penelitian berikutnya adalah penelitian yang dilakukan oleh Albelda (2011) yang menyebutkan bahwa akuntan manajemen merupakan fasilitator dari penerapan manajemen lingkungan. Selain itu terdapat pula hasil penelitian dari Clarke, 1994; Hart, 1997; Moore dan Miller, 1994; Office of Technology Assessment, 1994; Porter dan Van der Linde, 1995; Schmidheiny, 1992; Smart, 1992; dalam Theyel, 2000 dan De Giovanni, 2012, yang menjelaskan bahwa penerapan praktik manajemen lingkungan akan menyebabkan peningkatan pada kinerja lingkungan. Berdasarkan penelitian-penelitian tersebut maka pada disertasi ini akan diuji peran mediasi dari sistem informasi lingkungan sebagai penghubung antara peran akuntan manajemen dan kinerja lingkungan. Harapannya, dengan diterapkannya sistem informasi lingkungan, maka upaya untuk mencapai kinerja lingkungan menjadi lebih optimal.

$$
\begin{array}{rlr}
\text { H4 : } & \text { Peran akuntan } \\
& \text { manajemen melalui } \\
& \text { sistem informasi } \\
& \text { lingkungan } \\
& \text { berpengaruh terhadap } \\
& \text { kinerja lingkungan }
\end{array}
$$




\subsubsection{Sistem Informasi Lingkungan} dan Kinerja Lingkungan

Beberapa penelitian telah berupaya untuk dapat membuktikan pentingnya kinerja lingkungan. Namun pertanyaan mengenai bagaimana cara perusahaan dapat memak-simalkan kinerja lingkungan masih memerlukan kajian yang mendalam. Beberapa literatur menjelaskan bahwa perusahaan dapat memaksimalkan kinerja lingkungan dengan cara mengubah organisasi, strategi dan operasi bisnisnya untuk perbaikan terus-menerus (Theyel, 2000).

Perusahaan yang mengadopsi praktik pengelolaan lingkungan melakukan hal tersebut sebagai reaksi terhadap diberlakukannya undang-undang lingkungan, taat pada kewajiban, patuh pada peraturan, kekhawatiran atas daya saing perusahaan dan merespon kekhawatiran masyarakat atas degradasi lingkungan (Gottlieb, 1995; Porter dan Van der Linde, 1995; dalam Theyel, 2000). Praktik manajemen ini meliputi audit lingkungan, manajemen kualitas total (TQM), rencana pencegahan polusi, pelatihan lingkungan bagi karyawan, total cost accounting, analisis siklus hidup, menyewa manajer ling- kungan, RdanD, standar lingkungan untuk pemasok, dan program insentif karyawan untuk saran lingkungan (Dorfman et al, 1992; Garrod dan Chadwick, 1996; Maxwell et al, 1993; Shrivastava, 1996; Smart, 1992; dalam Theyel, 2000).

Beberapa peneliti yang mempelajari manajemen lingkungan mengklaim bahwa penerapan praktik manajemen lingkungan akan menyebabkan peningkatan pada laba dan kinerja lingkungan (Clarke, 1994; Hart, 1997; Moore dan Miller, 1994; Office of Technology Assessment, 1994; Porter dan Van der Linde, 1995; Schmidheiny, 1992; Smart, 1992; dalam Theyel, 2000).

Industri yang menerapkan praktik manajemen lingkungan melakukan transformasi dalam pengambilan keputusan bisnis dan perusahaan menyadari pentingnya kinerja lingkungan dalam kinerja perusahaan secara keseluruhan (Hart, 1997; Hart dan Ahuja, 1994; Maxwell et al, 1993; Schmidheiny, 1992; Smart, 1992; dalam Theyel, 2000). Misalnya, perusahaan menggunakan peningkatan kinerja lingkungan untuk 
menurunkan biaya dengan cara mengurangi sampah atas proses produksi (Shrivastava, 1996; dalam Theyel, 2000). Perusahaan juga mengurangi biaya kepatuhan lingkungan serta mengurangi ancaman perdata dan pidana atas polusi dengan cara mencegah pencemaran (Baram dan Partan, 1990; dalam Theyel, 2000).

Penelitian Theyel atas perusahaan kimia di AS menunjukkan bahwa terdapat pengaruh signifikan dari praktik manajemen lingkungan terhadap kinerja lingkungan. Praktik manajemen lingkungan yang banyak dilakukan oleh perusahaan meliputi audit atas limbah, TQM untuk pencegahan polusi, rencana pencegahan polusi dan program pelatihan karyawan untuk pencegahan polusi (Theyel, 2000).

Penelitian De Giovanni atas perusahaan yang terdaftar di Bursa Italia menunjukkan hasil bahwa manajemen lingkungan berpengaruh positif terhadap kinerja lingkungan. De Giovanni menyarankan bahwa jika perusahaan berencana untuk memperbaiki kinerja lingkungannya, maka perusahaan pertama-tama harus berkonsentrasi pada upaya-upaya implementasi manajemen lingkungan (De Giovanni, 2012).

Berdasarkan uraian di atas, penelitian ini ingin menguji pengaruh sistem informasi lingkungan terhadap kinerja lingkungan.

$$
\begin{aligned}
\text { H5 : } & \text { Sistem informasi } \\
& \text { lingkungan } \\
& \text { berpengaruh terhadap } \\
& \text { kinerja lingkungan }
\end{aligned}
$$

\section{Metode Penelitian}

\subsection{Rancangan Penelitian}

Model penelitian pada penelitian ini adalah sebagai berikut.

Model 1:

$\mathrm{SIL}=\alpha_{0}+\alpha_{1} \mathrm{KMP}+\alpha_{2} \mathrm{PAM}+\varepsilon$

Model 2:

$\mathrm{KNL}=\alpha_{0}+\alpha_{1} \mathrm{KMP}+\varepsilon$

$\mathrm{KNL}=\alpha_{0}+\alpha_{1} \mathrm{PAM}+\varepsilon$

$\mathrm{KNL}=\alpha_{0}+\alpha_{1} \mathrm{SIL}+\varepsilon$

\subsection{Pemilihan Sampel dan Pengumpulan Data}

Populasi dalam penelitian ini adalah perusahaan swasta yang berdomisili atau berkantor pusat di Jakarta. Metode pemilihan sampel menggunakan convenience sampling dan 
purposive sampling. Responden yang menjadi target dalam penelitian ini adalah para karyawan yang minimal telah menduduki tingkat supervisor. Penentuan kriteria responden dilakukan dengan pertimbangan bahwa yang bersangkutan telah memahami kebijakan dan operasional di dalam perusahaan.

Salah satu keterbatasan dalam penelitian ini adalah pada jumlah responden yang masih sedikit dan belum dapat mencerminkan jumlah populasi yang ada. Oleh karena itu, maka penelitian ini masih berupa pilot study yang dapat dikembangkan kembali untuk penelitian berikutnya.

\subsection{Indikator dan Pengukuran Variabel}

Dalam penelitian ini, indikator dan pengukuran atas variabel dapat dilihat pada tabel berikut.

Tabel 3.1

Indikator dan Pengukuran Variabel

\begin{tabular}{|c|c|c|}
\hline Variabel & Indikator & Pengukuran Variabel \\
\hline $\begin{array}{llr}\text { Komitmen } & \text { Manajemen } & \text { Puncak } \\
(\text { KMP) } & & \end{array}$ & KMP1 s.d KMP & $\begin{array}{l}\text { Skala Likert } \\
1=\text { sangat tidak setuju } \\
6=\text { sangat setuju }\end{array}$ \\
\hline Peran Akuntan Manajemen (PAM) & PAM1 s.d PAM9 & $\begin{array}{l}\text { Skala Likert } \\
1=\text { tidak penting } \\
6=\text { sangat penting }\end{array}$ \\
\hline Sistem Informasi Lingkungan (SIL) & SIL1 s.d SIL17 & $\begin{array}{l}\text { Skala Likert } \\
1=\text { tidak pernah } \\
6=\text { terus-menerus }\end{array}$ \\
\hline Kinerja Lingkungan (KNL) & KNL1 s.d KNL15 & $\begin{array}{l}\text { Skala Likert } \\
1=\text { sangat tidak setuju } \\
6=\text { sangat setuju }\end{array}$ \\
\hline
\end{tabular}

Sumber: Hasil olahan peneliti

\subsection{Metode Analisis Data}

Analisis data akan dilakukan dengan menggunakan metode analisis PLS (Partial Least Squares). Software yang digunakan untuk mengolah data pada penelitian ini adalah SmartPLS. Partial least squares merupakan metoda analisis yang powerfull dan 
sering disebut juga sebagai soft modeling karena meniadakan asumsiasumsi OLS (Ordinary Least Squares) regresi, seperti data harus terdistribusi normal secara mutivariate dan tidak adanya problem multikolonieritas antar variabel eksogen (Wold: 1985 dalam Hengky \& Ghozali: 2012, p6). PLS dikembangkan untuk menguji teori yang lemah dan data yang lemah seperti jumlah sampel kecil atau adanya masalah normalitas data (Wold: 1982 dalam Hengky \& Ghozali: 2012). Walaupun PLS digunakan untuk menjelaskan ada tidaknya hubungan antar variabel laten (prediction), PLS dapat juga digunakan untuk mengkonfirmasi teori (Chin dan Newsted: 1999 dalam Hengky \& Ghozali: 2012).

\subsubsection{Statistik Deskriptif}

Analisis atas statistik deskriptif digunakan untuk memberikan gambaran atau deskripsi empiris atas data yang dikumpulkan dalam penelitian. Jenis statistik deskriptif yang akan dianalisis meliputi nilai minimum, nilai maksimum, nilai rata-rata dan nilai modus.

\subsubsection{Evaluasi Model}

Model evaluasi pada PLS dilakukan dengan menilai outer model dan inner model. Evaluasi model pengu-kuran (outer model) dilakukan untuk menilai validitas dan reliabilitas model. Evaluasi model struktural (inner model) dilakukan untuk memprediksi hubungan antar variabel laten (Hengky \& Ghozali: 2012, p77)

(1) Outer model dengan indikator refleksif dievaluasi melalui:

a. Uji Validitas, yaitu validitas convergent dan discriminant dari indikator pembentuk konstruk laten.

- Discriminant Validity, Factor Loading, syarat $\geq 0,7$

- Convergent, Average Variance Extracted (AVE), syarat $\geq 0,5$

b. Uji Reliabilitas, yaitu composite reliability dan cronbach alpha untuk blok indikatornya.

- Cronbachs Alpha, syarat $\geq 0,6$

- Composite Reliability, syarat $\geq 0,7$ 
(2) Inner model dievaluasi dengan melihat besarnya persentase variance yang dijelaskan, yaitu dengan melihat nilai R-Square untuk konstruk laten endogen dan disebut juga dengan uji koefisien determinasi.

Untuk menguji kecocokan atau kelayakan suatu model (goodness of fit) maka digunakan angka koefisien determinasi $\left(\mathrm{r}^{2}\right)$. Koefisien determinasi merupakan proporsi variabilitas dalam suatu data yang dihitung angka tersebut menunjukkan garis regresi cocok dengan data secara sempurna. Model sesuai dalam menerangkan semua variabilitas dalam variabel $\mathrm{Y}$.

Jika $\mathrm{r}^{2}=0$, berarti tidak ada hubungan antara variabel $\mathrm{X}$ dengan variabel $\mathrm{Y}$.

Jika $0<\mathrm{r}^{2}<1$, berarti sekian persen variasi dari variabel $\mathrm{Y}$ (variabel dependen/ response), diterangkan dengan variabel $X \quad$ (variabel independen/ explanatory), sedangkan sisanya dipengaruhi oleh variabelvariabel yang tidak diketahui. Augustine dan Kristaung (2013).

\subsubsection{Uji Hipotesis}

Uji statistik t menunjukkan seberapa jauh pengaruh satu variabel independen secara individual dalam mene- berdasarkan pada model statistik. Koefisien determinasi merupakan rasio variabilitas nilai-nilai yang dibuat model dengan variabilitas nilai data asli. Dalam regresi, $r^{2}$ dijadikan sebagai pengukuran sebe-rapa baik garis regresi mendekati nilai data asli yang dibuat model. $\mathrm{R}^{2}$ dapat diartikan sebagai proporsi variasi tanggapan yang diterangkan oleh regresor (variabel independen) dalam model.Jika $r^{2}=1$, maka

rangkan variasi variabel dependen. Hipotesis nol (Ho) yang hendak diuji adalah apakah suatu parameter (bi) sama dengan nol, atau:

$\mathrm{Ho}=\mathrm{bi}=0$

Artinya, apakah suatu variabel independen bukan merupakan penjelas yang signifikan terhadap variabel dependen.

Hipotesis alternatif (Ha) yang hendak diuji adalah parameter suatu variabel tidak sama dengan nol, atau:

Ha : bi $\neq 0$

Artinya, variabel tersebut merupakan penjelas yang signifikan terhadap variabel dependen. 
Dalam SmartPLS, uji t dapat dilihat pada nilai $t$ statistic dan nilai $p$ value dan penilaian diambil berdasarkan nilai probabilitas (signifikansi)

dibandingkan dengan alpha $(\alpha)$ 5\%

Tabel 3.2

Penilaian Hasil Uji Hipotesis

\begin{tabular}{|c|c|}
\hline $\begin{array}{c}\text { Nilai } T \text { Statistic, syarat } \geq 1,96 \\
\text { (two tails) }\end{array}$ & $\begin{array}{c}\text { Nilai } P \text { Value, syarat } \leq 0,05 \\
\text { (two tails) }\end{array}$ \\
\hline $\begin{array}{l}\text { - Jika probabilitas (sig.) }<1,96 \text {, maka tidak } \\
\text { ada pengaruh yang signifikan antara } \\
\text { variabel terhadap variabel Y, dengan } \\
\text { tingkat kepercayaan } 95 \% \text {. } \\
\text { - Jika probabilitas (sig.) }>1,96 \text {, maka } \\
\text { terdapat pengaruh yang signifikan antara } \\
\text { variabel X terhadap variabel Y, dengan } \\
\text { tingkat kepercayaan } 95 \% \text {. }\end{array}$ & $\begin{array}{l}\text { - Jika probabilitas (sig.) }>\alpha(5 \%) \text {, maka tidak } \\
\text { ada pengaruh yang signifikan antara variabel } \\
\text { terhadap variabel Y, dengan tingkat } \\
\text { kepercayaan } 95 \% \text {. } \\
\text { - Jika probabilitas (sig.) < } \alpha(5 \%) \text {, maka } \\
\text { terdapat pengaruh yang signifikan antara } \\
\text { variabel X terhadap variabel Y, dengan } \\
\text { tingkat kepercayaan } 95 \% \text {. }\end{array}$ \\
\hline
\end{tabular}

Sumber: Hengky \& Ghozali (2012)

\section{Hasil Dan Pembahasan}

\subsection{Penentuan Sampel Penelitian}

Perusahan yang menjadi obyek penelitian adalah perusahaan swasta yang memiliki domisili dan beroperasi di wilayah DKI Jakarta. Responden adalah karyawan yang memiliki jabatan minimal sebagai penyelia (supervisor). Jumlah responden yang mengisi kuesioner adalah sebanyak 21 orang. 3 orang memiliki jabatan sebagai staf, sehingga tidak digunakan sebagai responden dalam penelitian ini. Jumlah kuesioner yang digunakan dalam penelitian ini sebanyak 18 kuesioner.

Sebagian besar responden dalam penelitian ini menduduki jabatan sebagai manajer. Selain bertanggung jawab dalam bidang akuntansi dan keuangan, para responden juga memiliki tanggung jawab di bidang pelaporan internal dan analisis keuangan. Secara rata-rata, para responden telah memiliki pengalaman minimal selama 4 tahun di dalam perusahaan. dengan demikian, latar belakang para responden dinilai cukup memadai untuk memberikan 
penilaian atau pendapat sesuai dengan pernyataan di dalam kuesioner.

Jenis industri perusahaan tempat responden bekerja cukup variatif. Sebagian besar berada di bidang perdagangan, jasa dan investasi. Selain itu, terdapat pula perusahaan yang bergerak di bidang aneka industri, pertanian, infrastruktur, utilias dan transportasi. Dengan adanya variasi ini maka jenis industri dapat mencerminkan keanekaragaman industri sehingga hasil penelitian diharapkan dapat digeralisasi untuk berbagai jenis industri.

Jenis perusahaan dibagi menjadi tiga, yaitu perusahaan lokal yang operasionalnya hanya meliputi wilayah DKI Jakarta, perusahaan nasional yang operasionalnya meliputi wilayah di Indonesia, dan perusahaan multinasional yang operasionalnya berada di beberapa negara. Sebagian besar perusahaan tempat responden bekerja adalah perusahaan dengan skala nasional. Dengan demikian, dari jenis skala perusahaan diharapkan dapat mencerminkan perusahaan- perusahaan yang beroperasional di wilayah Indonesia.

\subsection{Hasil Statistik dan Interpretasi}

Pada bagian ini peneliti menyajikan statistik deskriptif, uji koefisien determinasi dan uji regresi secara parsial untuk pengujian hipotesis.

Dari hasil output PLS diperoleh nilai adjusted $\mathrm{R}$-square sebagai berikut:

\section{Tabel 4.1}

Hasil Adjusted R Square

\begin{tabular}{cc}
\hline Variabel & $\begin{array}{c}\text { Nilai Adjusted } \\
R \text { Square }\end{array}$ \\
\hline SIL & 0,518 \\
\hline KNL & 0,824
\end{tabular}

Sumber: hasil olahan peneliti

Hasil uji koefisien determinasi menunjukkan bahwa Adjusted $R$ square untuk SIL adalah sebesar 0,518. Angka ini menunjukkan bahwa $51,8 \%$ variasi dari variabel SIL (variabel dependen/ response) dapat dijelaskan oleh variabel KMP dan PAM (variabel independen/ explanatory), sedangkan sisanya dipengaruhi oleh variabel-variabel lain yang tidak diketahui. 
Berikutnya, hasil uji koefisien determinasi menunjukkan bahwa Adjusted R-square untuk KNL adalah sebesar 0,824. Angka ini menunjukkan bahwa $82,4 \%$ variasi dari variabel KNL (variabel dependen/ response) dapat dijelaskan oleh variabel SIL (variabel independen/ explanatory), sedangkan sisanya dipengaruhi oleh variabelvariabel yang tidak diketahui.

Berdasarkan uji koefisien determinasi di atas, maka kecocokan atau kelayakan model (goodness of fit) dari penelitian ini dapat dikatakan cukup baik.

\subsubsection{Hasil Uji Hipotesis}

H1 : Komitmen manajemen puncak berpengaruh terhadap kinerja lingkungan

H2 : Komitmen manajemen puncak melalui sistem informasi lingkungan berpengaruh terhadap kinerja lingkungan

H3 : Peran akuntan manajemen berpengaruh terhadap kinerja lingkungan

H4 : Peran akuntan manajemen melalui sistem informasi lingkungan berpengaruh terhadap kinerja lingkungan

H5 : Sistem informasi lingkungan berpengaruh terhadap kinerja lingkungan

Hasil penelitian menunjukkan bahwa komitmen manajemen puncak memiliki pengaruh langsung terhadap kinerja lingkungan perusahaan. Artinya, komitmen manajemen puncak sangat dibutuhkan bagi perusahaan yang serius dalam peningkatan kinerja lingkungannya.

Sistem informasi lingkungan memediasi pengaruh komitmen manajemen puncak terhadap kinerja lingkungan, namun besarnya pengaruh masih lebih kecil dibandingkan pengaruh langsung komitmen manajemen puncak terhadap kinerja lingkungan.

Hal ini membuktikan bahwa untuk perusahaan yang menjadi sampel pada penelitian ini, sistem informasi lingkungan masih belum efektif dalam penerapannya. Perusahaan belum memiliki sistem informasi lingkungan yang memadai, sehingga peran dari sistem informasi ling- 
kungan ini belum dapat dirasakan oleh perusahaan.

Dari hasil kuesioner dapat diketahui bahwa manajemen puncak telah memberikan kontribusi kepada kinerja lingkungan atas produk atau jasa perusahaan, namun kontribusi tersebut masih belum maksimal diberikan.

Tabel 4.2

Hasil Pengujian Hipotesis

\begin{tabular}{lccc}
\hline \multicolumn{1}{c}{ Hipotesis } & $\begin{array}{c}\text { Nilai T } \\
\text { Statistic, } \\
\text { syarat } \\
\geq 1,96 \\
\text { (two tails })\end{array}$ & $\begin{array}{c}\text { Nilai Sig, } \\
\text { P values, } \\
\text { syarat } \leq 0,05 \\
\text { (two tails })\end{array}$ & $\begin{array}{c}\text { Terdukung/ } \\
\text { tidak } \\
\text { terdukung }\end{array}$ \\
& & & \\
\hline $\begin{array}{l}\text { H1: KMP berpengaruh terhadap } \\
\text { KNL }\end{array}$ & $\mathbf{4 , 9 9 3}$ & 0,000 & Terdukung \\
$\begin{array}{l}\text { H2: KMP melalui SIL berpengaruh } \\
\text { terhadap KNL }\end{array}$ & $\mathbf{2 , 3 3 5}$ & 0,031 & Terdukung \\
$\begin{array}{l}\text { H3: PAM berpengaruh terhadap } \\
\text { KNL }\end{array}$ & $\mathbf{3 , 5 3 2}$ & 0,002 & Terdukung \\
$\begin{array}{l}\text { H4: PAM melalui SIL berpengaruh } \\
\text { terhadap KNL }\end{array}$ & 1,668 & 0,113 & $\begin{array}{c}\text { Tidak } \\
\text { terdukung }\end{array}$ \\
H5: SIL berpengaruh terhadap KNL & 3,762 & 0,001 & Terdukung \\
\hline
\end{tabular}

Sumber: hasil olahan penelli

Manajemen puncak juga telah menetapkan bahwa informasi biaya lingkungan yang akurat meru-pakan hal penting bagi perusahaan. Manajemen puncak telah memberikan penekanan pada kinerja lingkungan dan memberikan perhatian pada pengembangan sistem informasi manajemen lingkungan yang efektif untuk membantu pengambilan keputusan. Saat ini, manajemem puncak juga telah menetapkan bahwa kinerja ling- kungan merupakan salah satu target yang paling penting untuk dicapai. Untuk itu, mereka bertanggung jawab secara pribadi atas kualitas kerja dan kinerja lingkungan perusahaan dengan terus mem-berikan arahan bahwa individu dalam perusahaan memiliki bagian penting dalam meningkatkan kinerja lingkungan.

Hasil penelitian menunjukkan bahwa akuntan manajemen memiliki peran dalam peningkatan kinerja ling- 
kungan perusahaan. Perusahaan yang ingin meningkatkan kinerja lingkungannya, selain membutuhkan komitmen dari manajemen puncak juga membutuhkan dukungan penuh dari para akuntan manajemennya. Namun sayangnya, sistem informasi lingkungan tidak terbukti dapat memediasi pengaruh peran akuntan manajemen terhadap kinerja lingkungan. Hal ini membuktikan bahwa para akuntan manajemen dalam menjalankan perannya belum menggunakan sistem informasi lingkungan yang memadai.

Hasil kuesioner menunjukkan bahwa peran akuntan manajemen di dalam perusahaan sudah cukup tinggi dan menjadi bagian yang sangat penting. Peran tersebut diwujudkan dalam pengelolaan manajemen biaya, penyediaan informasi biaya yang akurat dan transparan, pengurangan biaya, menetapkan standar, mem-perbaiki proses, mengurangi risiko dan berkontribusi pada strategi inti perusahaan. Peran tersebut baik secara langsung maupun tidak langsung tentunya akan terkait dengan masalah lingkungan.

Temuan lainnya dari penelitian ini memberikan bukti bahwa sistem informasi lingkungan berpengaruh terhadap kinerja lingkungan. Hal ini sesuai dengan tujuan penelitian yang ingin menunjukkan peran penting dari penerapan sistem informasi lingkungan pada perusahaan yang ingin meningkatkan kinerja lingkungannya.

Terkait dengan hasil temuan mengenai peran mediasi dari sistem informasi lingkungan maka sesuai dengan pendapat Baker dan Stocks (2007) yang menjelaskan bahwa penerapan sistem informasi lingkungan dalam organisasi membutuhkan proses yang cukup panjang.

Gambar 4.1

Pengembangan Sistem Informasi Lingkungan

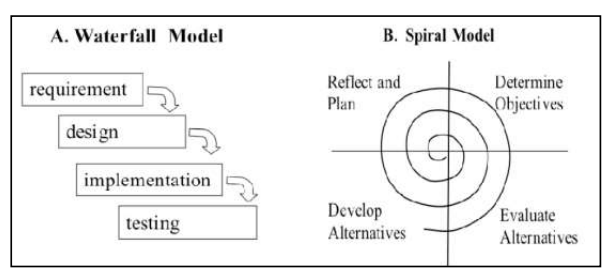

Sumber: Baker dan Stocks (2007: 6) 
Terdapat dua model dalam mengembangkan sistem informasi lingkungan, (1) linear waterfall model dan (2) iterative spiral model. Kedua model tersebut dapat dilihat pada gambar berikut ini.

Dari gambar di atas dapat dipelajari bahwa bila organisasi menerapkan model waterfall, maka organisasi akan mulai mengidentifikasi kebutuhan akan informasi ling-kungan, kemudian melakukan peran-cangan untuk sistem informasi lingkungan, kemudian mengimple-mentasikan sistem tersebut, dan akhirnya melakukan pengujian atas pelaksanaan sistem. Jika organisasi menerapkan model spiral, maka dimulai dari tahap penentuan tujuan, dilanjutkan dengan mengevaluasi berbagai alternatif yang ada, kemu-dian membangun alternatif tersebut dan menyusun rencana. Setelah rencana disusun, kembali organisasi akan menentukan tujuan berikutnya, melakukan evaluasi atas alternatif dan mengembangkan alternatif tersebut, diikuti dengan refleksi dan penyusunan rencana. Proses tersebut dilakukan terus-menerus.
Terkait dengan proses yang cukup panjang itu, maka penerapanan sistem informasi lingkungan me-rupakan proses evolusi, bukan proses revolusi. Efektivitas dari sistem informasi lingkungan ini akan dirasakan oleh perusahaan dalam jangka waktu yang cukup panjang. Namun dampak dari penerapannya dapat mulai dirasakan sedikit demi sedikit, dari periode ke periode dan akan berdampak pada meningkatnya kinerja lingkungan.

Hasil kuesioner menunjukkan bahwa kinerja lingkungan pada perusahaan di mana responden bekerja belum mengalami peningkatan. Kinerja lingkungan masih berada pada tingkat yang cukup rendah. Perusahaan sampai saat ini belum dapat menyusun laporan lingkungan baik secara internal maupun eksternal dengan kualitas yang baik. Perusahaan juga belum dapat menurunkan penggunaan bahan baku dan juga pengurangan pada emisi dan polusi udara. Selain itu, kinerja lingkungan yang masih rendah ini menyebabkan retensi dan daya tarik para staf terhadap perusahaan menjadi rendah. 
Dari uraian di atas dapat disimpulkan bahwa penerapan akuntansi manajemen lingkungan pada peru-sahaan yang menjadi sampel penelitian belum menunjukkan hasil yang optimal. Masalah lingkungan telah menjadi perhatian bagi manajemen maupun akuntan perusahaan. Mereka menyadari arti penting dari kinerja lingkungan. Namun sayangnya, penerapan dalam perusahaan masih harus terus ditingkatan.

\section{Kesimpulan dan saran}

\subsection{Kesimpulan}

a. Komitmen manajemen puncak berpengaruh terhadap kinerja lingkungan.

b. Komitmen manajemen puncak melalui sistem informasi lingkungan berpengaruh terhadap kinerja lingkungan.

c. Peran akuntan manajemen berpengaruh terhadap kinerja lingkungan.

d. Peran akuntan manajemen melalui sistem informasi lingkungan tidak berpengaruh terhadap kinerja lingkungan.

e. Sistem informasi lingkungan berpengaruh terhadap kinerja lingkungan.

\subsection{Saran}

Bagi perusahaan yang saat ini telah menjadikan kinerja lingkungan sebagai salah satu tujuan yang akan dicapai, diharapkan dapat menggunakan sistem informasi lingkungan untuk dapat mening-katkan kinerja lingkungan. Selain itu, komitmen dari manajemen puncak dan peran para akuntan manajemen juga harus terus ditingkatkan untuk memberikan hasil yang lebih optimal.

\subsection{Keterbatasan}

Salah satu keterbatasan dalam penelitian ini adalah pada jumlah responden yang masih sedikit dan belum dapat mencerminkan jumlah populasi yang ada. Oleh karena itu, maka penelitian ini masih berupa pilot study yang dapat dikembangkan kembali untuk penelitian berikutnya.

\section{Daftar Pustaka}

Albelda-Pe'rez, E., Correa-Ruiz, C., \& Carrasco-Fenech, F. (2007), Environmental Management Systems as an Embedding Mechanism: a Research Note, Accounting, Auditing and Accountability Journal, Vol. 20 No. 3, pp. 403-422.

Albelda, E. (2011), The Role of Management Accounting 
Practices as Facilitators of the Environmental Management: Evidence from EMAS Organisations, Sustainability, Accounting, Management and Policy Journal, Vol. 2 No. 1, pp. 76-100.

Adams, C. A., Muir, S., \& Hoque, Z. (2014). Measurement of Sustainability Performance in the Public Sector. Sustainability Accounting, Management and Policy Journal, Vol. 5 No. 1, pp. 4667.

Annandale, D., Morrison-Sauders, A. \& Bouma, G. (2004), The Impact of Voluntary Environmental Protection Instruments on Company Environmental Performance, Business Strategy and the Environment, Vol. 13 No. 1, pp. 1-12.

Augustine, Yvonne., dan Kristaung, Robert. (2013). Metodologi Penelitian Bisnis dan Akuntansi. Dian Rakyat.

Baker, S. Karen. \& Stocks, Karen I. (2007). Building Environmental Information Systems: Myths and Interdisciplinary Lessons. Proceeding of the 40th Hawaii International Conference on System Science.

Birkin, Frank. (1996). Environmental Management Accounting. Management Accounting. Vol 74. No. 2, pp. 34-37.

Burnett, R.D. and Hansen, D.R. (2008), Ecoefficiency:
Defining a Role for Environmental Management Cost Management", Accounting, Organizations and Society, Vol. 33, pp. 551581 .

Caliskan, A. O. (2014). How Accounting and Accountants May Contribute in Sustainability? Social Responsibility Journal. Vol. 10 No. 2, pp. 246-267.

Chartered Institute of Management Accountants (CIMA). (2011). Sustainability and the Role of the Management Accountant: Research Executive Summary Series. Volume 7. Issue 14.

De Giovanni, Pietro. (2012). Do internal and external environmental management contribute to the triple bottom line? International Journal of Operations \& Production Management, Vol. 32 No. 3, pp. 265-290.

Dong, L. (2001). Modeling Top Management Influence on ES Implementation. Business Process Management Journal, Vol. 7 No. 3, 2001, pp. 243-250.

Ilinitch, A. Y., Soderstrom, N. S. \& Thomas, T. (1998). Measuring Corporate Environmental Performance. Journal of Accounting and Public Policy. 17. Pp. 383-408.

Joshi, S., Krishnan, R. and Lave, L. (2001), Estimating the Hidden Costs of Environ-mental Regulation. Accoun-ting 
Review, Vol. 76 No. 2, pp. 171-198.

Lawrence, Lainy., Andrews, Duncan \& France, C. (1998). Alignment and Deployment of Environmental Strategy through Total Quality Management. The TQM Magazine, Vol. 10 Iss 4 pp. $238-245$.

Latan, Hengky \& Ghozali, Imam. (2012). Partial Least Squares: Konsep, Teknik dan Aplikasi Menggunakan Program SmartPLS 2.0 M3. Badan Penerbit Universitas Diponegoro. Semarang.

Martinez-Lorente, Angel R., Dewhurst, Frank \& Dale, Barrie G. (1998). Total Quality Management: Origins and Evolution of the Term. The TQM Magazine, Vol. 10 Iss 5 pp. $378-386$.

Medley, P. (1997). Environmental Accounting: What does It Mean to Professional Accountants? Accounting, Auditing \& Accountability Journal, Vol. 10 No. 4, 1997, pp. 594-600.

Mistry, V., Sharma, U. \& Low, M. (2014). Management Accountants' Perception of Their Role in Accounting for Sustainable Development: An Exploratory Study. Pacific Accounting Review. Vol. 26 No. 1/2, pp. 112-133.

Moneva, J. M., \& Ortas, E., (2010). Corporate Environmental and Financial Performance: a Multivariate Approach. Industrial Management \&
Data Systems, Vol. 110 No. 2, pp. 193-210.

Myburgh, J. E. (2001), "The informativeness of voluntary disclosure in the annual reports of listed industrial companies in South Africa", Meditari Accountancy Research, Vol. 9, pp. 199216.

Parker, L. D. (2000), "Green strategy costing: early days", Australian Accounting Review, Vol. 10 No. 1, pp. 4655.

Rego, A \& Cunha, M P. (2008). Workplace Spirituality and Organizational Commitment: an Empirical Study. Journal of Organizational Change Management. Vol. 21 No. 1. 2008. pp. 53-75.

Roy, M. J., Boiral, O. \& Lagace', D. (2001). Environmental Commitment and Manufacturing Excellence: a Comparative Study within Canadian Industry, Business Strate Gyand the Environment, Vol. 10 No. 5, pp. 257268.

Spencer, S. Y., Adams, C. \& Yapa, P.W.S. (2013). The Mediating Effects of the Adoption of an Environmental Information System on Top Management's Commitment and Environmental Performance. Sustainability Accounting, Management and Policy Journal, Vol 4 No. 1, pp. 75-102. 
Takagaki, Yukio. (2009). Japanese firms' environmental strategy: Example from electronics-related industries. Asian Business \& Management. Vol. 9, No. 2, pp. 245-264.

Theyel, Gregory (2000). Management Practices for Environmental Innovation and Performance. International Journal of Operations \& Production Management. Vol. 20 No. 2, 2000, pp. 249-266.

Tutuncu, Ozkan \& Kucukusta, Deniz (2007). Relationship between Organizational Commitment and EFQM Business Excellence Model: A Study on Turkish Quality Award Winners. Total Quality Management, Vol. 18, No. 10, pp1083-1096.
Tzempelikos, N. (2015). Top Management Commitment and Involvement and Their Link to Key Account Management Effectiveness. Journal of Business \& Industrial Marketing. pp. 3244.

Wee, Y. S. \& Quazi, H. A. (2005), Development and Validation of Critical Factors of Environmental Management, Industrial Management and Data Systems, Vol. 105 No. 1, pp. 96-114.

Yakhou, Mehenna \& Dorweiler, Vernon P. (2004). Environmental Accounting: an Essential Component of Business Strategy. Business Strategy and the Environment, Vol 13 No. 2, pp. 65-77. 